\title{
THE NECESSITY TO ORGANIZE LEARNER AUTONOMY IN THE PROCESS OF ACQUIRING FOREIGN LANGUAGE
}

\author{
L.V. Mikhaleva, Z.N. Levashkina
}

\begin{abstract}
The article considers the organization of learner autonomy in learning foreign language. The authors examine the term "autonomy" in modern methodological literature. The learner autonomy is interpreted differently by scientists and by now there is no a common explanation of this term. Despite different nuances we can certainly say that the learner autonomy is connected with a greater independence, the learners' responsibility in educational process, the ability to organize their own education and assess the results. Moreover it is paid attention to examination of the Language learning portfolio as an effective method of learner autonomy and the instrument of self-learning. It helps student to implement self-assessment and self-control of acquired linguistic skills that promotes the creating of conditions for development of educational competence and autonomy. The authors show the results of their research carried out with the students of the faculty of foreign languages of TSU to illustrate the effectiveness of the ELP.
\end{abstract}

Keywords: autonomy; learner autonomy; self-learning; knowledge selfassessment; European language portfolio.

\section{Introduction}

Many teachers currently focus their attention on continuous selflearning in different fields, including foreign languages. It is connected, on the one hand, with an integrative process covering all spheres of society's life, on the other hand, with individual needs to adapt quickly to the conditions of a constantly changing multicultural world.

The multinational structure of Europe and increased mobility in society require communicative skills in different languages. The concept of multilingualism is a principal approach of the European Council to the problem of language learning. Multilingualism involves the improvement of all linguistic skills rather than acquisition of several languages taken separately.

The development of students' independence attracts researchers' attention. In recent years, as a result of Russian integration into the Bologna Process, the attention of scientists and teachers in Russia to the term "autonomy" in foreign language learning has increased. This term was introduced into the educational context by the American researchers David Little, Henri Holec, Leslie Dickinson and others. A review of pedagogical and methodological literature demonstrates that the term "autonomy" is far from its final 
interpretation in modern pedagogics. Thus the issue of autonomy in the process of teaching a foreign language is relevant.

The purpose of this article is to demonstrate and define the instruments of the organization of autonomy in the process of learning a foreign language in an educational setting.

For this purpose, the following tasks were necessary: to examine the term "autonomy" in modern methodological literature; to describe the theoretical basis of the organization of learner autonomy; and to analyze the European Language Portfolio (ELP) as the effective method of the organization of learner autonomy and as a self-learning instrument.

\section{Methodology}

\section{Literature review}

As the theoretical basis of our research we applied the scientific works of Russian and other researchers in the following fields: the theory and methodology of higher education (S.I. Arkhangelsky, N.E. Astafieva, N.D. Galskova, V.P. Bespalko and others); the theory and methodology of foreign language teaching, linguistics, cross-cultural communication (E.N. Solovova, E.I. Passov, M.V. Verbizhkay and others); and learner autonomy (E.N. Solovova, N.F. Koryakovzheva, H. Holec, D. Little and others).

Rapid progress in science and education and the active integration of Russian institutions of higher education into the global educational system create a need for students' continuous self-education. For that, first of all, it is necessary to learn how to work "in your own scenario", that is, to develop learner autonomy [1. P. 23].

Russian methodists have studied the problem of learner autonomy as well (N.F. Korjakovzheva, I.V. Luksha, and E.N. Solovova).

\section{The term "Learner autonomy"}

Learner autonomy is defined and interpreted in different ways. The term "self-learning" of foreign language can be used and is defined as an independent training activity directed by educational and cognitive motivation [2].

Learner autonomy in educational activities lies in the person's ability to carry out the productive educational activities consciously, introspect and assess these activities, accumulate effective experience, and interact inventively and constructively with the educational environment. Students take on the responsibility for the process and the product of this activity as the result of self-determination and self-development [3. P. 16-17]. The study carried out by N.F. Korjakovzheva demonstrates the main characteristics of learner autonomy in the educational process as: 
1. Educational competence that has a basic component - having the strategy and method of training activities.

2. Position of business activity that includes the ability to engage in educational activity, and to show independent decision-making concerning all aspects of activities while taking on the responsibility for the result.

3. Position of structural and creative activity denotes students' orientation toward their personal educational product and its construction, their adaptability to different situations in their studies, their ability for creative transformation and interaction in a study group, and their transfer of individual experience to groupmates.

4. Position of reflective self-assessment that refers to the ability to self-assessment of the goals, the process and the product of educational activity, the introspection, the building of individual style of educational activity, and the transfer of experience in new educational contexts.

A "negative list" of what is not autonomy is given by Little [4], who supposes that the autonomy is not the synonym for self-learning, that is, it is not defined as studying without a teacher. Learner autonomy does not imply the lack of the teacher's responsibility for the educational process. At the same time, autonomy is not a method of teaching. The autonomy is not a characteristic that is constantly achieved by the learner.

The term "learner autonomy" can be interpreted as the realization of students' responsibility for the process and result of their educational activity. The teacher and the students are equal partners in the educational process and can choose their own trajectory of learning. The learner autonomy is identified with the ability to learn and person's necessity to self-learning [5]. The teacher's activity is the main condition of learner autonomy implementation for teaching a foreign language. This activity includes the development of new educational programs and textbooks, the introspection and assessment system of learner's autonomous activities.

E.N. Solovova connects the term "learner autonomy" and the understanding of learner's responsibility for the result and the process of learning. This term includes shared responsibility, the opportunity to choose, the flexibility in building own academic trajectory, the introspection and selfcontrol [6].

In the study carried out by G.S. Anikina "learner autonomy" is interpreted as the ability to set the goals of activities independently, to plan own actions, to choose the methods of education and the format of work carrying out the introspection, self-control and self-correction as well as being responsible for own results of learning and transferring them into new educational context [7. P. 151].

Hence the researchers do not have common definition of the term "learner autonomy". Each scientist puts in this term different nuances, but nevertheless the overall picture is clear. It is connected with a greater inde- 
pendence and responsibility that are placed on learners in the process of education, the ability to organize their education and assess the results.

\section{Learner Autonomy and Self-learning}

The term "autonomy" is often examined in comparison with the term "self-learning". Some scientists use the terms "autonomy" and "self-learning" as the synonyms (N.F. Korjakovzheva, T.Y. Ternovuh). Another group of researchers suppose that the terms "independent" and "autonomous" are equal and interchangeable (E.V. Apanovich, N.D. Galskova) [8. P. 170].

We should focus on the key differences between the terms "learner autonomy" and "self-learning". Firstly, the self-learning includes the part of the syllabus performed by the student (for instance, doing homework). The learner autonomy is the activities carried out by a student for his or her own purposes (the student's activities out of syllabus).

Secondly, the self-learning and the learner autonomy differ in a degree of responsibility for the result and process of studying. During the selflearning the student carries out the teacher's instructions, but in the learner autonomy on the contrary the student establishes individual educational objectives, selects the study materials, assesses the achieved results.

Thirdly, the self-learning implies a direct and indirect presence of teacher. The autonomy does not suppose the teacher's participation.

Finally, the self-learning is emphasized on the construction of educational activities without paying enough attention to the development of the individual educational activities [9. P. 342]. The concept of learner autonomy implies the idea of constant development and self-improvement of the individual in the sphere of acquiring the foreign language [10. P. 146].

The main feature of autonomy in the process of acquiring the foreign language is independent initiated students' attempt to exceed the limits of a fixed educational context. In our research the autonomy is interpreted as the highest level of independence of the subject of activity that implies the construction of individual trajectory of education and deliberate responsible display of creative initiative in the performed work.

\section{European Language Portfolio}

The most important tool of organizing learner autonomy is the European Language Portfolio (ELP) consisting of three parts: the Language Passport, the Language Biography and the Dossier. ELP is the instrument of selfassessment and individual cognitive and creative student's work, the introspection of his or her own activity.

The concept of the ELP broadens the framework of educational process by including the assessment model into student's achievements in authentic intercultural direct and mediate education [11]. 
In the ELP there is information about the student's level of proficiency in a foreign language according to the European Framework of Reference. The ELP offers six common reference levels. These levels include lower and higher sublevels in three-level system. It consists of elementary, intermediate and advanced levels. The scheme of levels is constructed by the principle of branching. It begins with the division into three main levels - A, B and C. Besides the levels "can do" descriptors are used to define the learner's proficiency at each level (e.g. the set of competences and skills that the learner can demonstrate).

The Language Learning Portfolio as a type of the ELP is one of the most promising in the methodological literature. This type of ELP contains particular recommendations for the students about self-learning of the studying language. Owing to such materials the student can independently improve interaction skills using authentic diagnostic tools (tests, questionnaires, self-assessment lists) that serve as an instrument of reflexive student's self-assessment and promote consecutive improvement of the learner's proficiency in a foreign language. This type of portfolio helps to develop the ability and willingness to autonomous learning of foreign language and foreign culture and gives students the opportunity to modify independently the amount and speed of material's delivery.

The ELP allows the learner to carry out self-assessment and selfcontrol of the acquired language skills. Well-known methodologists (E.N. Solovova, V.V. Saphronova and others) distinguish the following characteristics of the ELP: comprehensiveness, systematic character, informativeness, adaptiveness to the definite purpose, authenticity.

Self-control promotes the development of learners' introspection introducing sensible idea about their education into the process of control and assessment. It enhances the feeling of belonging to their work and increases the possibilities of a dialog between the students and the teacher concerning the purposes of educational course and progress in studies.

Thus the ELP in a way is a "mirror" of the process of studying a foreign language. The main components of this process are reflected in the ELP by means of the students' reflexive self-assessment that promotes creations of conditions for the development of their academic competence and autonomy [12].

\section{Experimental method}

We carried out the research based on usage of the ELP as the measuring instrument of the learner autonomy studying foreign language. Our work was realized during one academic year with third-year students of the Faculty of Foreign Languages in Tomsk State University getting a second degree. The autonomous work for such students is a major component of academic work. As an example we take the ELP of one student. 
The structure of the ELP consists of three parts (the Language Passport, the Biography and the Dossier) and includes general information about the student; the table and checklist for self-assessment; the texts and the tasks carried out by the student. In the Dossier there are the materials from the textbook "Proficiency Masterclass: Student's book" by K. Gude and M. Duckworth. This book is designed for the students who have quite high English level.

The first part of the ELP includes the points to fill in that show the general information about its owner. This part contains the name and surname of student, the information about the place and date of birth and nationality. Also there are the paragraphs such as "Stay abroad" where the student writes the country, the city, the year / duration and the purpose of the trip, and "Projects" where the student has to point out the themes of projects which he took part in and new acquired knowledge / skills. This information corresponds to the part "Language Passport" in the ELP. The student noted down a visit in Italy in 2012 within a month as a tourist.

The second part includes the "Self-evaluation grid" where the student assesses his or her level of knowledge and skills in a foreign language by the aspects of speech activity - speaking, reading, listening and writing according to the European Framework of Reference. In the "Self-assessment checklist" the student ticks what he or she can and cannot do now but thinks to be important for him and establishes the objectives.

The third part of the ELP represents the informative complex where the student collects the texts and independently performed tasks.

At first the student was asked to assess language level and establish the objectives in the self-assessment checklists B2 (Vantage or upper intermediate), that is the competences of quite high level of lexical and grammatical, listening, reading and writing skills.

In the first column the student marked what he or she can do now at the beginning of the year and evaluates the skills. The student identified the suitable description and put a tick.

The tested student did not tick the section "Listening" that indicates the existence of insufficient skills to understand oral reports on the abstract and specific subjects. The monologue and writing skills were evaluated higher. The reading was assessed with the maximal amount of ticks, in other words this skill is the most formed: the student understands the texts on different themes.

Then the student proceeded to filling in the first part of the ELP and fulfilling the tasks based on the proposed texts and materials. After that the student marked what he or she has learnt in the second column of the selfassessment checklist. The system of evaluation was the same, with "ticks".

On completion of this step, the positive tendency in the English skills of the student was observed. Based on the student's self-evaluation we saw 
the predominant amount of ticks in the second column of the checklist. It means that now the student can do a lot with ease.

The final step included the completion of the tasks and evaluation of the acquired knowledge at the end of the academic year in the third column of the checklist.

\section{Results}

We converted the findings into numeric value and graphed in the Table. The X-axis displays the time period: the beginning and the end of the academic year. The Y-axis is the amount of positive responses or "ticks".

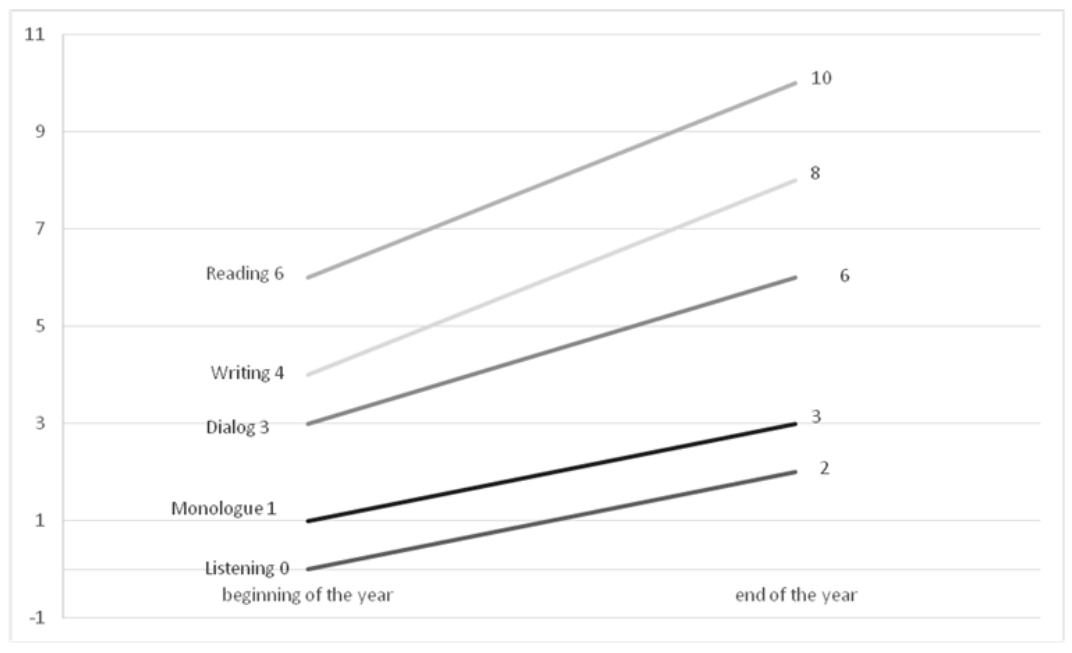

Fig. 1. The dynamics of knowledge and skills' changes

The table shows that the acquirement of skills had a positive tendency (fig. 1). By the end of the academic year the student marked four new ticks both in reading and writing, in dialog - three, in monologue - two, in listening - one. In other words we can see the development in reading, writing and dialog.

There is the same situation with the ELP of other students taking part in the research. However the given example is the most representative since English level of the present student at the beginning of the academic year was relatively low and the dynamics of all indices at the end of the year was the most significant.

\section{Conclusion}

The results of the work have shown that the tested student evaluated the available skills as satisfying the requirements of B2 level. Thus the stu- 
dent can establish new language objectives namely go on to higher level (C1) and gain knowledge and skills that is correspondent to the given level.

The results of studies represented in the ELP give students and teachers the opportunities to accumulate independently and estimate the volume of work and the progress level of language study and culture. Also the ELP helps to form the adequate self-evaluation of personal activities, to practise self-control, to promote cognitive activity and develop the skills of life-long education.

Thus the ELP is one of the effective methods in the organization of learner autonomy in foreign language teaching.

\section{References}

1. Anikina G. S., Agaphonova L. I. (2009) Razvitie uchebnoj avtonomii pri obuchenii inostrannomu yazyku [The development of learner autonomy in learning of foreign language: the history of the problem in the foreign pedagogics] // Vestnik TGU - TSU Journal. Vol. 4 (82). pp. 23 - 27.

2. Kapaeva A. E. (2001) O formirovanii gotovnosti uchashhixsya k samoobucheniyu inostrannomu yazyku [Building-up the learners' readiness at self-learning of foreign languages] // Innostrannye yazyki v shkole - Foreign languages in school. № 3. pp. 12 - 17 .

3. Korjakovzheva N. F. (2001) Avtonomiya uchashhegosya v proczesse izucheniya inostrannogo yazyka i kul'tury [Learner autonomy in the process of learning foreign language and culture] // Vestnik MGLU - MSLU Journal. Vol. 461. pp. 12 - 29.

4. Little D. (1991) Learner autonomy: definitions, issues and problems. Dublin.

5. Luksha I. V. (2008) Yazykovaya laboratoriya kak sredstvo optimizaczii uchebnoj avtonomii $v$ mul'timedijnom professional'no orientirovannom kontekste (na primere fakul'teta inostrannyx yazykov pedagogicheskogo vuza) [The linguistic laboratory as the method of optimization of learner autonomy in rich media professional-oriented context (by the example of the faculty of foreign languages of pedagogical university)]: Abstract of Doctoral Diss. Moscow.

6. Solovova E. N. (2004) Metodicheskaya podgotovka i perepodgotovka uchitelya inostrannogo yazyka: integrativno-refleksivnyj podxod [Methodologicaltraining and retraining for teachers of foreign language: integrated and reflexive approach]. Moscow.

7. Anikina G. S. (2011) Uchebnaya avtonomiya kak neot"emlemyj komponent processa obucheniya inostrannomu yazyku v XXI veke [Educational autonomy as an integral component of the process of learning foreign language in the 21st century] // Vestnik TGUTSU Journal. № 344. pp. 149 - 152.

8. Prokhorezh E. K., Mishakova E. A. (2010) Avtonomiya kak faktor intensifikaczii uchebnogo proczessa po inostrannomu yazyku v neyazykovom vuze [The autonomy as a factor of intensification of educational process in foreign language in non-linguistic university] // Filologicheskie nauki. Voprocy teoorii i praktiki - Philological Sciences. Issues of Theory and Practice. Vol. 2. pp. 169 - 173.

9. Davidov V.V. (1996) Teoriya razvivayushhegosya obucheniya [The theory of developmental education]. M.: INTOR.

10. Nasonova E. A. (2010) Analiz interpretaczij ponyatiya "uchebnaya avtonomiya" [The analysis of the "learner autonomy" interpretations] // Teoriya i praktika prepodavaniya gumanitarnyx discziplin - Theory and practice of teaching the humanities. Izvestiya vuzov. Seriya "Gumanitarnye nauki". [Proceedings of universities. Series "The humanities"]. pp. 145 - 149. 
11. Labazina L. N. (2003) Evropejskij yazykovoj portfel' - sredstvo oczenki i samooczenki znanij uchashhixsya po inostrannym yazykam [The Language Learning Portfolio - the instrument of assessment and self-assessment of students' knowledge in foreign languages] // Yaroslavskij pedagogicheskij vestnik - Yaroslavl pedagogical journal. № 2 (35).

12. Fedorova L. A. (2013) Yazykovoj portfel' uchenika kak variant individualizirovannoj oczenki soczial'noj i lingvisticheskoj kompetenczii uchashhixsya [Language portfolio as a version of individualized assessment of social and linguistic competence of learners] / Festival' pedagogicheskix idej "Otkrytyj urok" - The festival of pedagogical ideas "Open lesson". [Online]. Available from: http://festival.1september.ru/articles/591517/ [Accessed: 20.04.2013].

Received 20 June 2016

\title{
УЧЕТ НЕОБХОДИМОСТИ ОРГАНИЗАЦИИ АВТОНОМНОЙ РАБОТЫ ПРИ ОБУЧЕНИИ ИНОЯЗЫЧНОМУ ОБЩЕНИЮ Михалёва Л.В., Левашкина 3.Н.
}

DOI $10.17223 / 19996195 / 35 / 14$

\begin{abstract}
Аннотация. Статья посвящена организации автономной работы учащихся. Показаны и определены средства организации автономной работы в учебном процессе при изучении иностранного языка. Авторы статьи уделяют внимание рассмотрению понятия «автономия» в современной методической литературе, описанию теоретических основ организации автономной работы учащихся, а также рассмотрению Европейского языкового портфеля как эффективного средства организации автономной работы учащихся и инструмента самообучения.
\end{abstract}

Ключевые слова: автономия; автономное обучение; самообучение; самооценка знаний; Европейский языковой портфель.

\section{Сведения об авторах:}

Левашкина Зоя Николаевна - ст. преподаватель кафедры английской филологии факультета иностранных языков Томского государственного университета (Томск, Россия). E-mail: zoyagulit@sibmail.com 